\title{
Chromosomal Mapping and Cloning of the Lipase Gene of Pseudomonas aeruginosa
}

\author{
By SUSANNE WOHLFARTH* AND ULRICH K. WINKLER \\ Ruhr-Universität Bochum, Lehrstuhl für Biologie der Mikroorganismen, D-4630 Bochum, FRG
}

(Received 13 April 1987; revised 24 September 1987)

\begin{abstract}
Various mutants (lip) of Pseudomonas aeruginosa PAO 2302 that lacked extracellular lipase activity were isolated. They were selected on a calcium-triolein agar. The phenotypic characteristics of two of these mutants suggested that they were defective in the gene coding for lipase: both lip mutants produced no lipase in liquid- and on solid medium. They were nonpleiotropic with regard to various other exoproducts. None of the mutants released any putatively cell-bound lipase after treatment of cells with Triton X-100 or alginate. The electrophoretic protein- and LPS-profiles of outer membranes derived from lip mutants and the parental strain were identical. The lip locus was mapped on the chromosome of $P$. aeruginosa PAO 1 by FP5- and R68.45-mediated crossings and by transduction with phage G101. The lip locus was cotransduced with pyrF only $(60 \%)$ indicating a map position at about $57 \mathrm{~min}$. The lipase gene was cloned on a $3.1 \mathrm{~kb}$ Sall fragment using vector pKT248. The newly constructed plasmid was able to complement the lipase deficiency of the two lip mutants of $P$. aeruginosa.
\end{abstract}

\section{INTRODUCTION}

Pseudomonas aeruginosa is an opportunistic pathogen causing life-threatening infections especially in patients suffering from cystic fibrosis or having a compromised immune system. Several extracellular proteins produced by $P$. aeruginosa, e.g. exotoxin A, elastase, phospholipase $C$ and exoenzyme $S$, were considered as virulence factors (Govan \& Harris, 1986; Winkler et al., 1985). The pathogenic role of the extracellular lipase is unknown so far. Besides this clinical aspect, the lipase of $P$. aeruginosa is also of interest in biotechnology as it specifically catalyses trans- and interesterifications (Lazar, 1985).

The lipase of $P$. aeruginosa PAC $1 \mathrm{R}$ is a lipid-hydrolysing enzyme (EC 3.1.1.3) excreted into the medium during the late exponential growth phase. It has an apparent $M_{\mathrm{r}}$ of 29000 and the native enzyme is strongly associated with lipopolysaccharide (LPS) (Stuer et al., 1986).

In this paper we report on the physiological characterization of newly isolated lipase-deficient (lip) mutants from P. aeruginosa PAO 2302 and on the chromosomal mapping and cloning of the corresponding gene. Some of the results described were presented at the EMBO workshop 'Genetic Manipulation of Pseudomonads - Applications in Biotechnology and Medicine', Geneva, 31 August to 4 September, 1986.

\section{METHODS}

Bacteria, plasmids and phage. All Pseudomonas aeruginosa strains used were derivatives of wild-type $P$. aeruginosa PAO 1 (ATCC 15692). They are listed in Table 1.

Auxotrophic donors carrying the conjugative resistance plasmids FP5 (Matsumoto \& Tazaki, 1973) or R68.45 (Haas \& Holloway, 1976) were constructed as described by Haas \& Holloway (1976) and Haas et al. (1977) using $P$. aeruginosa PAO 4020 (FP5) or $P$. aeruginosa PAO 25 (R68.45) as donors of the desired plasmid. For transductional analysis phage G101 was used (Holloway \& van de Putte, 1968). In cloning experiments Escherichia

\footnotetext{
Abbreviations: NB, nutrient broth; LB, Luria broth; CT, calcium-triolein; NG, $N$-methyl- $N^{\prime}-$ nitro- $N$ nitrosoguanidine.
} 


\section{Table 1. Strains of $P$. aeruginosa used in this study}

\begin{tabular}{ll}
\multicolumn{1}{c}{ Strain } & \multicolumn{1}{c}{ Genotype* } \\
PAO 1 & Prototroph \\
PAO 8 & met-28 ilv-202 str-1 \\
PAO 25 & argF-10 leu-10 \\
PAO 166 & leu-10 pyrF \\
PAO 325 & argB-18 lys-57 \\
PAO 388 & aro-1 pyrF69 pur-70 \\
PAO 436 & ser-3 bla-436 \\
PAO 2302 & catAl met-9020 puuAl \\
PAO 4020 & nir-9006 his-9004 str-9002 \\
PAO 4044 & met-9020 catA1 nar-9011 \\
& mtu-9002 tyu-9030 dcu-9041 \\
29-1 & met-9020 catA1 puuA1 lip1 \\
29-4 & met-9020 catAl puuAl lip1 arg \\
6-1 & met-9020 catA1 puuAl lip2 \\
6-4 & met-9020 catA1 puuAl lip2 arg
\end{tabular}

Holloway et al. (1979)

Isaac \& Holloway (1968)

Haas \& Holloway (1976)

Royle et al. (1981)

Isaac \& Holloway (1972)

Royle et al. (1981)

Krishnapillai et al. (1981)

Matsumoto et al. (1978)

Matsumoto et al. (1981)

Matsumoto et al. (1981)

$\left.\begin{array}{l}\text { NG derivative of PAO 2302 } \\ \text { NG derivative of 29-1 } \\ \text { NG derivative of PAO 2302 } \\ \text { NG derivative of 6-1 }\end{array}\right\} \begin{aligned} & \text { This } \\ & \text { study }\end{aligned}$

Plasmid

Phenotype

R68.45

FP5

pKT248

$\mathrm{Cb}^{R} \mathrm{Km}^{\mathrm{R}} \mathrm{Tc}^{\mathrm{R}}$
$\mathrm{Hg}^{\mathrm{R}}$
$\mathrm{Sm}^{\mathrm{R}} \mathrm{Cm}^{\mathrm{R}}$

Haas \& Holloway (1976)

Matsumoto et al. (1981)

Bagdasarian et al. (1981)

* Symbols were used according to Holloway et al. (1979); lip, deficiency in extracellular lipase activity.

coli-P. aeruginosa shuttle-vector pKT248 $\left(\mathrm{Sm}^{\mathrm{R}} \mathrm{Cm}^{\mathrm{R}}\right)$ was used (Bagdasarian et al., 1981). E. coli strains SK 1108 $\left(\mathrm{F}^{-}\right.$pyrF $\mathrm{Km}^{\mathrm{R}}$ gal thi sup Ti-R hsdR-4 endA sbcB-15) from Donovan \& Kushner (1983) and JM109 (recAl endAl gyrA96 thi hsdR17 supE44 relAI $\lambda-\Delta\left(\right.$ lac-proAB) $\mathrm{F}^{\prime}$ traD36 proAB lacl' $\mathrm{Z} \Delta \mathrm{M} 15$ ) (Yanisch-Perron et al., 1985) were used as heterologous cloning hosts.

Media and growth conditions. Strains of $P$. aeruginosa were usually grown in nutrient broth (NB; Difco) under aeration at $37^{\circ} \mathrm{C}$. Three different minimal selection media (each solidified with $1.5 \%$, w/v, Bacto-agar) were used. (i) Minimal medium M9 (Maniatis et al., 1982) when selecting for prototrophic revertants of amino acid auxotrophs. When necessary, amino acids were added to the medium at a final concentration of $0.1 \mathrm{mM}$. (ii) Minimal medium according to Ornston \& Stanier (1966) when selecting for cells utilizing unusual carbon sources such as mannitol, benzoic acid, tyrosine and diaminopimelic acid. These carbon sources were added to a final concentration of $10 \mathrm{~mm}$. (iii) Minimal medium according to Davis \& Mingioli (1950) to select for bacteria independent of adenine, uracil and aromatic amino acids; final concentrations of supplements were $0.1 \mathrm{~mm}$.

To distinguish between clones of lipase-excreting $\left(l i p^{+}\right)$and -defective (lip) bacteria, a newly developed plate test using calcium-triolein (CT) agar was applied. Demineralized water $(45 \mathrm{ml})$ and purified olive oil $(5 \mathrm{ml})$ were vigorously stirred for $15 \mathrm{~min}$ on a magnetic stirrer. This mixture and $5 \mathrm{ml}$ of a $1 \%(\mathrm{w} / \mathrm{v}) \mathrm{CaCl}_{2}$ solution were added to $450 \mathrm{ml} \mathrm{NB}$ agar (containing $4 \mathrm{~g} \mathrm{NB}, 2 \mathrm{~g} \mathrm{NaCl}$ and $7.5 \mathrm{~g}$ agar). During continuous stirring for another 5-10 min the solution was aseptically adjusted to $\mathrm{pH} 7.5$. All solutions were previously sterilized by autoclaving ( $20 \mathrm{~min}$; $200 \mathrm{kPa}$ ). The agar plates contained little oil droplets on the surface of the solidified medium. Inoculated plates were incubated at $30^{\circ} \mathrm{C}$.

For phenotypic characterization of lip mutants different agar plate tests were used. (i) Hydrolysis of triolein. For medium composition see above. lip ${ }^{+}$colonies showed white crystals (calcium oleate) on top whereas lip colonies did not. (ii) Hydrolysis of Tween 80. Test conditions according to Howe \& Ward (1976). (iii) Hydrolysis of gelatin. NB agar contained $0.4 \%$ Bacto-gelatin. Hydrolysis could be detected as clear zones surrounding the colonies after pouring $0.5 \mathrm{M}$-sulphuric acid (saturated with $\mathrm{Na}_{2} \mathrm{SO}_{4}$ ) onto the agar. (iv) Hydrolysis of elastin. $\mathrm{NB}$ agar contained $0.3 \%$ elastin (Sigma). Hydrolysis resulted in clear zones around the colonies. (v) Hydrolysis of lecithin. One eggyolk was aseptically mixed into $250 \mathrm{ml} \mathrm{NB}$ agar. Hydrolysis was indicated by the formation of white precipitates under the colonies (Gerhardt et al., 1981). (vi) Pyocyanin production. This was best on peptone-glycerol agar (Gerhardt et al., 1981). Fluorescein production was assayed on NB agar, pH 6.0, supplemented with $\mathrm{MgSO}_{4}$ $(0.15 \%)$. The latter showed yellow fluorescence when irradiated with UV light (about $265 \mathrm{~nm})$ (Gerhardt et al., 1981).

Additionally, we used Luria broth (LB) (Maniatis et al., 1982) and LB agar (solidified with $1.5 \%$, w/v, agar) while working with $E$. coli strains. Streptomycin sulphate $\left(50 \mu \mathrm{g} \mathrm{ml}^{-1}\right)$ or chloramphenicol $\left(20 \mu \mathrm{g} \mathrm{m}^{-1}\right)$ were added to LB, NB and CT agar for selection purposes.

Mutagenesis. P. aeruginosa PAO 2302 was grown in NB to late exponential growth phase, washed in $20 \mathrm{mM}-$ 
potassium phosphate buffer, $\mathrm{pH} \mathrm{6.0,} \mathrm{and} \mathrm{treated} \mathrm{with} 50 \mu \mathrm{g} \mathrm{N}$-methyl- $N^{\prime}$-nitro- $N$-nitrosoguanidine (NG) $\mathrm{ml}^{-1}$ for $7 \mathrm{~min}$ at $37^{\circ} \mathrm{C}$. Frequency of survivors was about $15 \%$.

Conjugation and transduction. Conjugations using mobilization plasmid FP5 were done in NB according to Matsumoto et al. (1981). Both donor and recipient strain were grown to mid-exponential growth phase and usually mixed in volume ratios of $1: 1 ; 1: 2$ or $1: 5$. Matings were done without any agitation at $37^{\circ} \mathrm{C}$ for $3 \mathrm{~h}$. Samples $(0.1 \mathrm{ml})$ of washed $(0.9 \% \mathrm{NaCl})$ cells were plated onto selective media.

Using plasmid R68.45, matings were done on plates. Donor and recipient cells of exponential growth phase were concentrated to $6 \times 10^{9}$ cells $\mathrm{ml}^{-1}$ in $0.9 \% \mathrm{NaCl}$ before they were mixed and plated onto selective media (Stanisich \& Holloway, 1972).

Transduction with phage G101 was done according to Matsumoto et al. (1981). Cells from exponential growth phase cultures were concentrated to $10^{9}$ cells ml ${ }^{-1}$ in TNM buffer $(10 \mathrm{mM}-\mathrm{Tris} / \mathrm{HCl}, \mathrm{pH} 7 \cdot 4,150 \mathrm{mM}-\mathrm{NaCl}$, $10 \mathrm{mM}-\mathrm{MgSO}_{4}$ ) and phage was added to give a multiplicity of infection of five to seven. After preadsorption the cells were concentrated tenfold and plated onto selective media.

Preparation of outer membranes. This was done using the Sarkosyl method of Lambert \& Booth (1982). The membrane proteins were solubilized at $90{ }^{\circ} \mathrm{C}$ for $10 \mathrm{~min}$ in an SDS-buffer system. They were electrophoretically separated on a $14 \%(\mathrm{w} / \mathrm{v})$ acrylamide $/ 0.12 \%$ bisacrylamide gel and then stained with Coomassie brilliant blue $\mathrm{G}$. Electrophoretic LPS-profiles were obtained by SDS solubilization (see above) and proteinase $\mathrm{K}$ digestion $\left(0.4 \mathrm{mg} \mathrm{ml}^{-1}, 60 \mathrm{~min}\right.$ at $\left.50^{\circ} \mathrm{C}\right)$ of outer membrane preparations examined by electrophoresis on $12 \%(\mathrm{w} / \mathrm{v})$ acrylamide $/ 5 \%(\mathrm{w} / \mathrm{v})$ bisacrylamide gels and silver staining (Tsai \& Frasch, 1982).

Enzyme assays. Lipase activity was assayed spectrophotometrically using $p$-nitrophenyl palmitate as substrate (Winkler \& Stuckmann, 1979). In addition, a bioluminescent lipase assay (Ulitzur, 1979) was used to measure very low lipase activities. In this test the enzymic release of myristic acid from trimyristin was followed by the fattyacid-dependent bioluminescence of a dim mutant of Vibrio harveyi. All lipase assays were done at least twice. Esterase activity was assayed spectrophotometrically with palmitoyl-CoA as substrate (Ohkawa et al., 1979).

Molecular genetic methods. Chromosomal DNA of $P$. aeruginosa PAO 1 was prepared as described by Maniatis et al. (1982). Plasmids were isolated according to Birnboim \& Doly (1979) and further purified by centrifugation to equilibrium in ethidium-bromide- $\mathrm{CsCl}$ gradients. Restriction endonuclease digestions and ligations were done as recommended by the supplier (BRL). E. coli was transformed by a $\mathrm{CaCl}_{2}$-method described by Maniatis $e$ t al . (1982). For the transformation of $P$. aeruginosa we used cells from early-exponential growth phase cultures washed twice with $150 \mathrm{mM}-\mathrm{MgCl}_{2}$. After overnight incubation in $150 \mathrm{mM}-\mathrm{MgCl}_{2}$ at $4{ }^{\circ} \mathrm{C}$ cells were competent (Olsen et al., 1982).

\section{RESULTS}

\section{Isolation and phenotypic characterization of lip mutants}

$P$. aeruginosa PAO 2302 was treated with NG in two independent mutagenesis batches. About $0.4 \%$ of the total number of colonies screened $(n \approx 16000)$ did not show lipase activity on CT agar. Many of these were pleiotropic mutants as were those described by Wretlind \& Pavlovskis (1984) and were therefore not investigated.

Two independent lip mutants, strains 29-1 and 6-1 seemed to be non-pleiotropic and were phenotypically characterized in detail. When tested on CT agar neither produced an extracellular lipase. Enzyme assays confirmed that both mutants also did not produce extracellular and cell-bound lipase in liquid media - neither in minimal medium M9 nor in NB at $30^{\circ} \mathrm{C}$ or $37^{\circ} \mathrm{C}$. They still had a cell-bound esterase able to hydrolyse Tween 80 , p-nitrophenyl palmitate and palmitoyl-CoA (Table 2).

When $P$. aeruginosa PAO 2302 was incubated in the presence of $0.2 \%$ alginate the extracellular lipase activity increased by a factor of about eight (Table 3 ), as expected from experiments with other strains [alginate is assumed to detach cell-bound lipase (Wingender \& Winkler, 1984)]. However, neither of the lip mutants showed any response to alginate (Table 3 ). Likewise, treatment of lip mutants with Triton X-100 (0.02\%), which solubilizes some membrane-bound proteins, did not release any lipase activity from the cells.

lip mutants 29-1 and 6-1 were of the non-pleiotropic type with respect to their ability to hydrolyse gelatin, elastin and lecithin (Table 4). Formation of the pigments pyocyanin and fluorescein was not influenced either (Table 4). These results suggested that no central excretion pathway of extracellular products was mutationally altered.

The two lip mutants and the corresponding parental strain PAO 2302 showed the same electrophoretic banding pattern when their outer membrane proteins and LPSs were studied by 
Table 2. Lipase and esterase activities of P. aeruginosa PAO 2302 and the two lip mutants

Cells grown in $\mathrm{NB}$ medium at $30^{\circ} \mathrm{C}$ for $16 \mathrm{~h}$ to stationary phase were removed from the culture medium by centrifugation. Enzyme activities were measured in the cleared supernatants. Substrates were trimyristine $(a)$, p-nitrophenyl palmitate $(b)$ and palmitoyl-CoA $(c)$. All enzyme activities were standardized for equal cell density $\left(O D_{580}=1\right)$.

\begin{tabular}{|c|c|c|c|c|c|}
\hline \multirow[b]{3}{*}{ Strain } & \multicolumn{5}{|c|}{ Enzyme activity (nmol $\min ^{-1} \mathrm{ml}^{-1}$ ) } \\
\hline & \multicolumn{3}{|c|}{ Extracellular } & \multicolumn{2}{|c|}{ Cell-bound } \\
\hline & (a) Lipase & $\begin{array}{l}\text { (b) Lipase and } \\
\text { Esterase }\end{array}$ & (c) Esterase & $\begin{array}{l}\text { (b) Lipase and } \\
\text { Esterase }\end{array}$ & (c) Esterase \\
\hline $\begin{array}{l}\text { Parental strain } \\
\text { PAO } 2302\end{array}$ & 24 & 145 & 0.950 & $47 \cdot 6$ & 7 \\
\hline $\begin{array}{l}\text { lip mutants } \\
29-1 \\
6-1\end{array}$ & $\begin{array}{l}0.001 \\
0.042\end{array}$ & $\begin{array}{l}2 \cdot 6 \\
3 \cdot 2\end{array}$ & $\begin{array}{l}0.770 \\
0.785\end{array}$ & $\begin{array}{l}8 \cdot 7 \\
9 \cdot 1\end{array}$ & $\begin{array}{l}4 \cdot 7 \\
4 \cdot 4\end{array}$ \\
\hline
\end{tabular}

Table 3. Extracellular lipase activity of $P$. aeruginosa PAO 2302 and the two lip mutants in the absence and presence of exogenous alginate

Lipase activity was measured in the supernatants of bacterial cultures grown at $30^{\circ} \mathrm{C}$ to stationary phase $(23 \mathrm{~h})$ in M9 minimal medium supplemented with $0.1 \mathrm{~mm}$-methionine. Enzyme activities $(p-$ nitrophenyl palmitate as substrate) were standardized to equal cell density $\left(\mathrm{OD}_{580}=1\right)$ and corrected for quenching due to bacterial pigments.

\begin{tabular}{|c|c|c|c|}
\hline \multirow[b]{2}{*}{ Strain } & \multicolumn{2}{|c|}{$\begin{array}{l}\text { Lipase activity } \\
\left(\mathrm{nmol} \mathrm{min}^{-1} \mathrm{ml}^{-1}\right)\end{array}$} & \multirow{2}{*}{$\begin{array}{l}\text { Stimulation } \\
\text { factor }\end{array}$} \\
\hline & - Alginate & + Alginate $*$ & \\
\hline $\begin{array}{l}\text { Parental strain } \\
\text { PAO } 2302\end{array}$ & 59 & 447 & $7 \cdot 6$ \\
\hline $\begin{array}{l}\text { lip mutants } \\
29-1 \\
6-1\end{array}$ & $\begin{array}{l}1 \cdot 7 \\
2 \cdot 2\end{array}$ & $\begin{array}{l}1 \cdot 2 \\
1 \cdot 0\end{array}$ & $\begin{array}{l}0 \\
0\end{array}$ \\
\hline
\end{tabular}

* Alginate (Manucol LB) was added to a final concentration of $0 \cdot 2 \%$.

Table 4. Phenotypic characterization of $P$. aeruginosa PAO 2302 and the two lip derivatives based on agar plate tests

+ , Wild-type activity; - , no activity; $+/-$, very little activity.

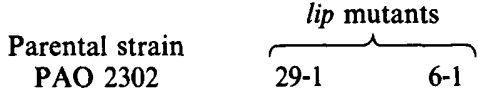

$\begin{array}{llcc}\begin{array}{l}\text { Hydrolysis of: } \\ \text { triolein }\end{array} & + & - & - \\ \begin{array}{l}\text { Tween } 80 \\ \text { gelatin }\end{array} & + & +1- & +1- \\ \text { elastin } & + & + & + \\ \text { lecithin } & + & + & + \\ \begin{array}{l}\text { Formation of: } \\ \text { pyocyanin }\end{array} & + & + & + \\ \text { fluorescein } & + & + & + \\ & + & + & +\end{array}$

SDS-PAGE (Fig. 1). This indicated that the missing extracellular lipase activity of the mutants was not due to structural changes of outer membrane components involved in exoenzyme excretion. 
(a)

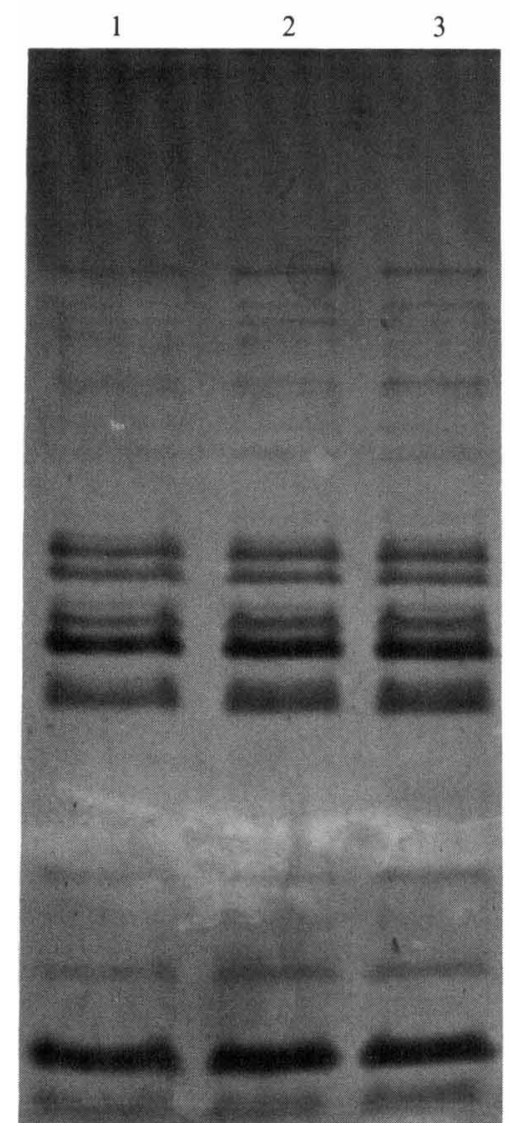

(b)

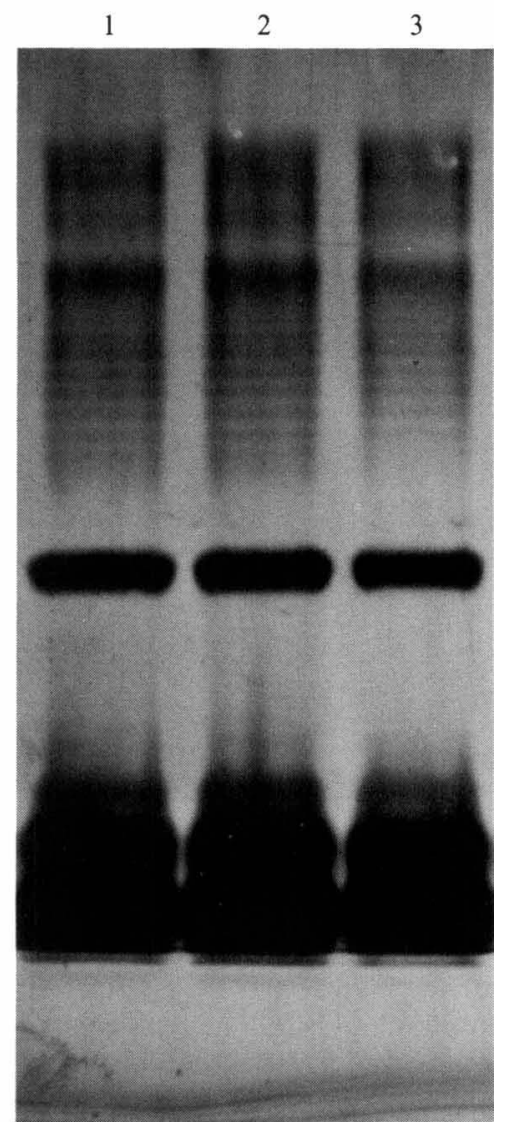

Fig. 1. PAGE of outer membrane proteins (a) and LPS profile (b) of $P$. aeruginosa PAO 2302 (lane 1) and the lip derivatives 29-1 (lane 2) and 6-1 (lane 3).

\section{Genetic mapping of the lip locus}

The chromosomal location of the mutations in both lip mutants was determined by crossing and transduction experiments.

Crossing experiments using plasmid FP5 for chromosome mobilization (Table $5 a$ ) allowed a rough localization of lip loci of both mutants at later than 50 min on the chromosome of $P$. aeruginosa PAO 1 (we refer to the map of $P$. aeruginosa PAO 1 chromosome published by Holloway \& Matsumoto in 'Genetic Maps 1984'). A more detailed map position was obtained by R68.45-mediated crossings (Table $5 b$ ). The loci of both lip mutants were found to be in the 55$64 \mathrm{~min}$ region on the bacterial chromosome with the closest linkage (93-95\%) to the selective marker pyrF.

Bacteriophage G101 was used for transductional analysis. Selecting for seven different markers [leu-10 (54 min); met-9011 (55 min); pyrF63 (57 min); dcu-9041 (60 min); catAl (64 min); $m t u-9002(70 \mathrm{~min}) ; t y u-9030(75 \mathrm{~min})]$ gave cotransduction frequencies of $58 \%(29-1)$ and $60 \%(6-1)$ of the non-selective lip marker with pyrF63 only.

\section{Cloning of the lipase gene}

$P$. aeruginosa PAO 1 DNA was partially digested with restriction endonuclease SalI and ligated into the single $S a l$ Iite of the shuttle-vector pKT248. Transformants of $E$. coli SK 1108 were selected for streptomycin resistance and contraselected for chloramphenicol sensitivity. 
Table 5. Linkage of the lip locus of mutants 29-1 and 6-1 to selective markers of $P$. aeruginosa $P A O$ in FP5- and R68.45-mediated crossings

Selective marker

(a) FP5-mediated crossings

$\operatorname{argF}$

leu-10

met -9011

cat A1/met-9011

(b) R68.45-mediated crossings

$\arg B$

lys-57

ser-3

aro- 1

leu-10

met-9011

pyrF63

aro-1/pyrF63

dcu-9041

catAl

cat $11 /$ met -9011

mtu-9002

tyu-9030

pur-70

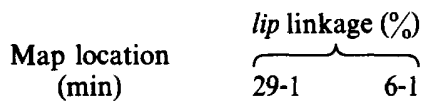

$\begin{array}{lrr}45 & 0 & 0 \\ 54 & 3 & 0 \\ 55 & 59 & 57 \\ 55 / 64 & 95 & 95\end{array}$

21 NT $\quad 0$

20 NT $\quad 0$

$30 \quad \mathrm{NT} \quad 0$

$53 \quad 2 \quad 10$

$54 \quad 1 \quad 2$

$55 \quad 24 \quad 25$

$57 \quad 93 \quad 95$

$53 / 57 \quad 92 \quad 90$

$60 \quad 16 \quad 27$

$\begin{array}{lll}64 & 18 & 14\end{array}$

$55 / 64 \quad 96 \quad 96$

$70 \quad$ NT 4

$\begin{array}{lll}75 & 0 & 1\end{array}$

$89 \quad 0 \quad 0$

NT, Not tested.

Six-thousand clones were divided into 120 portions each consisting of 50 clones. Mixed plasmid preparations were obtained from each portion and used to transform $P$. aeruginosa lip mutant 6-1. Selection was made on CT agar supplemented with streptomycin.

One recombinant plasmid named pSW1 could be selected with a SalI insert of $3.1 \mathrm{~kb}$ composed of a $1.3 \mathrm{~kb}$, a $0.97 \mathrm{~kb}$ and a $0.76 \mathrm{~kb}$ Sall subfragment.

This plasmid fully complemented the lip phenotype of both lipase-defective mutants (29-1 and 6-1) of $P$. aeruginosa. With regard to lipase excretion no differences could be detected between the parental strain PAO 2302 and the lip mutant derivatives carrying plasmid pSW1. In E. coli JM109(pSW1), however, no lipase activity was found extracellularly at different growth phases. When cells of $E$. coli JM109(pSW1) were disrupted by sonication the intracellular lipase activity was below $1 \mathrm{nmol} \mathrm{min}{ }^{-1} \mathrm{ml}^{-1}$ using $p$-nitrophenyl palmitate as enzyme substrate. Experiments to subclone the fragment and insert it into a strong $E$. coli expression vector are under way.

Nevertheless, using other selection media we found two independent recombinant plasmids with a $5.3 \mathrm{~kb}$ or a $10 \mathrm{~kb} S a l I$ insert complementing the $p y r F$ phenotype of $E$. coli SK 1108 .

\section{DISCUSSION}

Phenotypic differences were used by Wretlind \& Pavlovskis (1984) to distinguish between two classes of exoproduct-deficient mutants of $P$. aeruginosa: class I are mutants defective in exporting exoproducts, and class II are mutants defective in the regulation of exoproduct formation. The lip mutants $29-1$ and 6-1 we have isolated and phenotypically characterized do not belong to either of these classes. Both mutants were not pleiotropic with regard to the formation of various exoproducts. Neither showed any extracellular lipase activity, on solid media or in broth cultures. Compartmental analysis of our mutants did not indicate any intracellular accumulation of lipase activity (data not shown). Furthermore, treatment of the mutants either with Triton X-100 or with alginate did not cause any release of putatively cellbound lipase activity into the medium. The electrophoretic banding pattern of proteins and LPSs were alike when the outer membranes from lip mutants and their parental strain were compared. In summary, the data suggested that our lip mutants did arise by mutations in the structural gene for lipase. 
The results of conjugational and transductional analysis of lip mutants 29-1 and 6-1 were in good agreement with the above conclusion because the new mutant loci were not identical with any loci so far published and known to be involved in regulation and/or secretion of exoproducts in P. aeruginosa. The mutations of both our lip mutants were located at map position $57 \mathrm{~min}$ on the chromosome, closely linked and cotransduced with pyrF63 only. Mutations interfering with regulation and/or secretion of exoproducts, however, are located at $0 \mathrm{~min}(x c p-1), 35 \mathrm{~min}$ ( $x c p-2$, $x c p-3), 40 \mathrm{~min}(x c p-4), 55 \mathrm{~min}(x c p-5, x c h-1, x c h-2)$ and $67 \mathrm{~min}(x c p-6)$ (Wretlind \& Pavlovskis, 1984; Björklind et al., 1985; Filloux et al., 1987).

Structural genes for exoproducts of $P$. aeruginosa neither prefer a certain map position on the chromosome nor do they tend to cluster as indicated by the following data: at $20 \mathrm{~min}-\mathrm{plcA}, B$ (phospholipase C) (Gray \& Vasil, 1981); at $23 \mathrm{~min}$ - exoenzyme S (Nikas, 1986); at $57 \mathrm{~min}$ - lip (lipase) (this study); at 35 and $67 \mathrm{~min}$ - pvd (pyoverdine) (Hohnadel et al., 1986); at $75 \mathrm{~min}$-las A (elastase) (Howe et al., 1983); and at $85 \mathrm{~min}$ - toxA (exotoxin A) (Hanne et al., 1983).

Using vector pKT248 it was possible to clone a $3 \cdot 1 \mathrm{~kb}$ fragment of DNA from $P$. aeruginosa PAO 1 which was able to fully complement the lipase deficiency of lip mutants 29-1 and 6-1. This insert probably contained the structural gene for lipase. After transfer of this new plasmid (called pSW1) to E. coli JM109 traces of lipase activity could be detected in the cells. The low expression of the lipase gene was not surprising because of the poor recognition of Pseudomonas promoters in E. coli (Jeenes et al., 1986). Subcloning of the lipase gene and sequencing will enable us to see whether the base sequence will meet the expectations based on the apparent $M_{\mathrm{r}}$ (29000) of the lipase estimated from SDS-PAGE (Stuer et al., 1986).

When preparing this manuscript a recent paper by Odera et al. (1986) came to our attention reporting the cloning of a lipase gene from a newly isolated soil bacterium identified as $P$. aeruginosa. These authors used plasmid RP4:Mucts62 for in vivo cloning and found good expression of the cloned lipase gene also in E. coli. Furthermore, Kugimiya et al. (1986) published work on the cloning of a lipase gene from $P$. fragi. Preliminary comparison of some data from Kugimiya et al. (1986) and from our group (Stuer et al., 1986) suggests that $P$. aeruginosa and $P$. fragi produce different lipases.

We gratefully acknowledge the excellent technical assistance of Mrs Petra Wahl. We thank Drs D. Haas, B. W. Holloway, S. Kushner, H. Matsumoto, K. Timmis, S. Ulitzur and B. Wretlind for kindly supplying us with bacterial strains, plasmids and phages. Part of this work was financially supported by the Deutsche Gesellschaft zur Bekämpfung der Mucoviscidose.

\section{REFERENCES}

Bagdasarian, M., Lurz, R., RÜCKert, B., Franklin, F. C. H., Bagdasarian, M. M., Frey, J. \& Timmis, K. N. (1981). Specific-purpose plasmid cloning vectors. II. Broad host range, high copy number, RSF1010-derived vectors, and a host-vector system for gene cloning in Pseudomonas. Gene 16, 237-247.

Birnboim, H. C. \& Doly, J. (1979). A rapid alkaline extraction procedure for screening recombinant plasmid DNA. Nucleic Acids Research 7, 1513-1523.

BJöRKLIND, A., WRETliND, B., MöllegÅRD, I., Schad, P. A., Iglewski, B. H. \& Cox, C. D. (1985). Genetic mapping and characterization of Pseudomonas aeruginosa mutants that hyperproduce exoproteins. Journal of Bacteriology 162, 1329-1331.

Davis, B. D. \& Mingioli, E. S. (1950). Mutants of Escherichia coli requiring methionine or vitamin $\mathbf{B}_{12}$. Journal of Bacteriology 60, 17-28.

Donovan, W. P. \& Kushner, S. R. (1983). Cloning and physical analysis of the $p y r F$ gene (coding for orotidine-5'-phosphate decarboxylase) from Escherichia coli K-12. Gene 25, 39-48.

Filloux, A., Murgier, M., Wretlind, B. \& LazDUNSKI, A. (1987). Characterization of two Pseudo- monas aeruginosa mutants with defective secretion of extracellular proteins and comparison with other mutants. FEMS Microbiology Letters 40, 159163.

Gerhardt, P., Murray, R. G. E., Costilow, R. N., Nester, E. W., WoOD, W. A., KRIEG, N. R. \& Phillips, G. B. (1981). Manual of Methods for General Bacteriology. Washington, DC: American Society for Microbiology.

Govan, J. R. W. \& HARris, G. S. (1986). Pseudomonas aeruginosa and cystic fibrosis: unusual bacterial adaptation and pathogenesis. Microbiological Sciences 3, 302-308.

GraY, G. L. \& VASIL, M. L. (1981). Mapping of a gene controlling the production of phospholipase $\mathrm{C}$ and alkaline phosphatase in Pseudomonas aeruginosa. Molecular and General Genetics 183, 403-405.

HAAS, D. \& HollowaY, B. W. (1976). R factor variants with enhanced sex factor activity in Pseudomonas aeruginosa. Molecular and General Genetics 144, 243251.

HaAs, D., Holloway, B. W., Schamböck, A. \& LEISINGER, T. (1977). The genetic organization of 
arginine biosynthesis in Pseudomonas aeruginosa. Molecular and General Genetics 154, 7-22.

HANNe, L. F., Howe, T. R. \& IGLewsKi, B. H. (1983). Locus of the Pseudomonas aeruginosa toxin A gene. Journal of Bacteriology 154, 383-386.

HohNadel, D., HAAS, D. \& MEYeR, J.-M. (1986). Mapping of mutations affecting pyoverdine production in Pseudomonas aeruginosa. FEMS Microbiology Letters 36, 195-199.

Holloway, B. W. \& Matsumoto, H. (1984). Pseudomonas aeruginosa. In Genetic Maps 1984, vol. 3, pp. 194-197. Edited by S. J. O'Brien. Cold Spring Harbor, New York: Cold Spring Harbor Laboratory.

Holloway, B. W. \& VAN DE PUTTE, P. (1968). Lysogeny and bacterial recombination. In Replication and Recombination of Genetic Material, pp. 175183. Edited by W. J. Peacock \& R. D. Brock. Australian Academy of Science.

Holloway, B. W., Krishnapillai, V. \& Morgan, A. F. (1979). Chromosomal genetics of Pseudomonas. Microbiological Reviews 43, 73-102.

HOWE, T. G. B. \& WARD, J. M. (1976). The utilization of Tween 80 as carbon source by Pseudomonas. Journal of General Microbiology 92, 234-235.

Howe, T. R., WRETLIND, B. \& IGLEWSKI, B. H. (1983). Comparison of two methods of genetic exchange in determination of the genetic locus of the structural gene for Pseudomonas aeruginosa elastase. Journal of Bacteriology 156, 58-61.

IsAaC, J. H. \& HollowaY, B. W. (1968). Control of pyrimidine biosynthesis in Pseudomonas aeruginosa. Journal of Bacteriology 96, 1732-1741.

IsAaC, J. H. \& HollowaY, B. W. (1972). Control of arginine biosynthesis in Pseudomonas aeruginosa. Journal of General Microbiology 73, 427-438.

JeEnes, D. J., Soldati, L., BaUR, H., Watson, J. M., Mercenier, A., ReimmanN, C., Leisinger, T. \& HAAs, D. (1986). Expression of biosynthetic genes from Pseudomonas aeruginosa and Escherichia coli in the heterologous host. Molecular and General Genetics 203, 421-429.

Krishnapillai, V., Royle, P. \& Lehrer, J. (1981). Insertions of the transposon $\mathrm{Tn} 1$ into the Pseudomonas aeruginosa chromosome. Genetics 97, 495-511.

KUgImiYa, W., Otani, Y., Hashimoto, Y.\& TAKaGi, Y. (1986). Molecular cloning and nucleotide sequence of the lipase gene from Pseudomonas fragi. Biochemical and Biophysical Research Communications 141, 185-190.

LAMBERT, P. A. \& BOOTH, B. R. (1982). Exposure of outer membrane proteins on the surface of Pseudomonas aeruginosa PAO I revealed by labelling with [125I]lactoperoxidase. FEMS Microbiology Letters $14,43-45$.

LAzAR, G. (1985). Estersynthesen mit Lipasen. Fette Seifen Anstrichmittel 87, 394-400.

Maniatis, T., Fritsch, E. F. \& SambrooK, J. (1982). Molecular Cloning: a Laboratory Manual. Cold Spring Harbor, New York: Cold Spring Harbor Laboratory.

Matsumoto, H. \& TAZAKI, T. (1973). FP5 factor, an undescribed sex factor of Pseudomonas aeruginosa. Japanese Journal of Microbiology 17, 409-417.

Matsumoto, H., Nakazawa, T., OHta, S. \& TerawaKI, Y. (1981). Chromosomal locations of cat $A, p o b A, p c a A, d c u$ and $c h u$ genes in Pseudomonas aeruginosa. Genetical Research 38, 251-266.
Matsumoto, H., Ohta, S., Kobayash, R. \& TERAWAKI, Y. (1978). Chromosomal location of genes participating in the degradation of purines in Pseudomonas aeruginosa. Molecular and General Genetics 167, 165-176.

NIKAS, T. I. (1986). Genetic mapping of a gene regulating the production of exoenzyme $\mathrm{S}$ in Pseudomonas aeruginosa PAO. In Abstracts of EMBOworkshop: Genetic Manipulation of Pseudomonads Applications in Biotechnology and Medicine (Geneva, 31 August-4 September, 1986).

Odera, M., TAKeUChI, K. \& TOH-E, A. (1986). Molecular cloning of lipase genes from Alcaligenes denitrificans and their expression in Escherichia coli. Journal of Fermentation Technology 64, 363-371.

Ohrawa, I., Shiga, S. \& Kageyama, M. (1979). An esterase on the outer membrane of Pseudomonas aeruginosa for the hydrolysis of long chain acyl esters. Journal of Biochemistry 86, 643-656.

Olsen, R. H., DeBusscher, G. \& McCombie, W. R. (1982). Development of broad-host-range vectors and gene banks: self-cloning of the Pseudomonas aeruginosa PAO chromosome. Journal of Bacteriology 150, 60-69.

ORnston, L. N. \& Stanier, R. Y. (1966). The conversion of catechol and protocatechuate to $\beta$ ketoadipate by Pseudomonas putida. Journal of Biological Chemistry 241, 3776-3786.

Royle, P. L., Matsumoto, H. \& Holloway, B. W. (1981). Genetic circularity of the Pseudomonas aeruginosa PAO chromosome. Journal of Bacteriology 145, 145-155.

Stanisich, V. A. \& Holloway, B. W. (1972). A mutant sex factor of Pseudomonas aeruginosa. Genetical Research 19, 91-108.

STUER, W., JAEGER, K.-E. \& WiNkLER, U. K. (1986). Purification of extracellular lipase from Pseudomonas aeruginosa. Journal of Bacteriology 168, 10701074.

TSAI, C.-M. \& FrasCh, C. E. (1982). A sensitive silver stain for detecting lipopolysaccharides in polyacrylamide gels. Analytical Biochemistry 119, 115-119.

ULITZUR, S. (1979). A sensitive bioassay for lipase using bacterial bioluminescence. Biochimica et biophysica acta 572, 211-217.

WINGENDER, J. \& WINKLER, U. K. (1984). A novel biological function of alginate in Pseudomonas aeruginosa and its mucoid mutants: stimulation of exolipase. FEMS Microbiology Letters 21, 63-69.

WinkLER, U. K. \& STUCKMANN, M. (1979). Glycogen, hyaluronate, and some other polysaccharides greatly enhance the formation of exolipase by Serratia marcescens. Journal of Bacteriology 138, 663-670.

WINKLER, U., WINGENDER, J. \& JAEGER, K.-E. (1985). Infektionen der Atemwege mit Pseudomonas aeruginosa bei der Cystischen Fibrose. Klinische Wochenschrift 63, 490-498.

Wretlind, B. \& Pavlovskis, O. R. (1984). Genetic mapping and characterization of Pseudomonas aeruginosa mutants defective in the formation of extracellular proteins. Journal of Bacteriology 158, 801808.

Yanisch-Perron, C., Vieira, J. \& Messing, J. (1985). Improved M13 phage cloning vectors and host strains: nucleotide sequences of the $\mathrm{M} 13 \mathrm{mp} 18$ and pUC19 vectors. Gene 33, 103-119. 